\title{
The Impact of the Organizational Culture and Leadership Style on Nurses' Job Satisfaction: An Integrative Review
}

\author{
Nashi Masnad Alreshidi* \\ Regional Nursing Administration in Hail Region, Saudi Arabia
}

*Corresponding author: Nashi Masnad Alreshidi, Phd RN MSN, Continuing Nursing Education Director, Regional Nursing Administration in Hail Region, Saudi Arabia.

Submission: 㯺 May 08, 2018; Published: 眥 May 17, 2018

\author{
Background \\ Job satisfaction promotes efficiency and productivity among health care professionals including nurses. Organizational culture and leadership \\ style were viewed to affect job satisfaction and staff retention [1].
}

Keywords: Organizational culture; Job satisfaction; Leadership style; Nurse

\section{Introduction}

This integrative literature review aimed to discuss the impact of organizational culture and the leadership style on nurses' job satisfaction and staff retention [2].

\section{Methods}

Electronic searching for EBSCO, CINAHL, Scopus and Ovid SP databases was performed for the period between 1990 and 2015 [3].

\section{Results}

Of 420 retrieved studies, ninety eight studies were included in this review. The discrepancy between nurses' and leaders' perceptionsinrelation to the leadershipbehaviours was problematic. Organizational behaviour is a belief of influencing nurses to know what is required from skills, values, and assumptions. The robust organizational structure which combines values and believes in the working place yields the best performance and higher proficiency. The transformational leadership style gained the superiority over transactional leadership style. Job retention was particularly influenced by both professional commitment and job satisfaction.
The effective leadership style improves both job satisfaction and staff retention [4].

\section{Conclusion}

The organizational structure and staff values must be fully understood to reach the target level of satisfaction. In addition, nursing leaders should approximate their beliefs to the nurses' perceptions to meet their job expectations.

\section{References}

1. Jesus C, Pinto ZG (2008) Leadership-organizational culture relationship in nursing units of acute care hospitals. Nursing Econ 26(1): 7-15.

2. Rad AM, Mohammadian Y (2006) A study on the relationship between managers leadership style and employees job satisfaction. Int J Health Care Qual Assur Inc Leadersh Health Serv 19(2-3).

3. Ravasi D, Schultz M (2006) Responding to organizational identity threats: Exploring the role of organisation culture. The Academy of Management Journal 49(3): 433-458.

4. Lok P, Crawford J (2004) The effect of organizational culture and leadership style on job satisfaction and organizational commitment: A cross-national comparison. The Journal of Management Development 23(4): 321-338. 


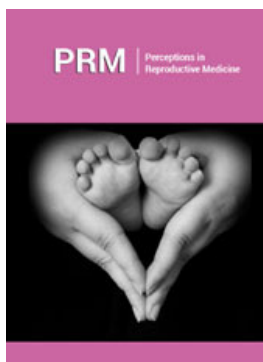

Perceptions in Reproductive Medicine

\section{Benefits of Publishing with us}

For possible submissions Click Here

Submit Article

- High-level peer review and editorial services

- Freely accessible online immediately upon publication

- Authors retain the copyright to their work

- Licensing it under a Creative Commons license

- Visibility through different online platforms 